\title{
Using Diets to Reveal Overlap and Egg Predation among Benthivorous Fishes in Lake Michigan
}

\author{
Justin G. Mychek-Londer* \\ School of Natural Resources and Environment, University of Michigan, Dana Building, \\ 440 Church Street, Ann Arbor, Michigan 48109, USA
}

David B. Bunnell and Wendylee Stott

U.S. Geological Survey, Great Lakes Science Center, 1451 Green Road, Ann Arbor, Michigan 48105, USA

James S. Diana
School of Natural Resources and Environment, University of Michigan, Dana Building,
440 Church Street, Ann Arbor, Michigan 48109, USA

John R. P. French III and Margret A. Chriscinske

U.S. Geological Survey, Great Lakes Science Center, 1451 Green Road, Ann Arbor, Michigan 48105, USA

\begin{abstract}
Ecological stability in the Laurentian Great Lakes has been altered by nonindigenous species, such as the Round Goby Neogobius melanostomus and dreissenid mussels, and by declines in native amphipods Diporeia spp. We evaluated whether these changes could influence diet overlap between three benthivorous fishes (Slimy Sculpin Cottus cognatus, Deepwater Sculpin Myoxocephalus thompsonii, and Round Goby) and whether predation on eggs of native species was occurring. We examined diets of fish collected at depths of 69-128 m in Lake Michigan offshore of Frankfort and Muskegon, Michigan, and Two Rivers and Sturgeon Bay, Wisconsin, during January-May 2009 and 2010. Important prey (by dry weight proportion and by percent frequency of occurrence) for Slimy Sculpin were Mysis $(0.34 ; 45 \%)$, Diporeia $(0.16 ; 34 \%)$, and Limnocalanus macrurus $(0.22 ; 68 \%)$; important prey for Deepwater Sculpin were Mysis $(0.74 ; 92 \%)$ and Diporeia $(0.16 ; 54 \%)$. Round Goby consumed mainly bivalves (i.e., dreissenids: 0.68; 95\%) and Mysis $(0.15 ; 37 \%)$. The two sculpin species consumed the eggs of Bloaters Coregonus hoyi (Slimy Sculpin: 0.04, 11\%; Deepwater Sculpin: 0.02, 7\%) and the eggs of Deepwater Sculpin (Slimy Sculpin: 0.03, 13\%; Deepwater Sculpin: 0.05, 16\%) during February-May at all sites. Round Goby also consumed eggs of these species but at lower levels $(\leq 0.01 ;<1 \%)$. Diet overlap was identified between sculpin species at Frankfort and Sturgeon Bay, suggesting possible interspecific competition, but their diets did not overlap at Two Rivers; diet overlap was never observed between Round Goby and either sculpin species. Given that (1) diet overlap varied by site and (2) diet proportions varied spatially more than temporally, benthivores appear to be exhibiting localized responses to recent ecological changes. Overall, these results reveal that egg predation and interspecific competition could be important interactions to consider in future examinations of the population dynamics of these species or in ecosystem models that forecast how fisheries will respond to possible perturbations or management scenarios.
\end{abstract}

Aquatic ecosystems have been dramatically altered by anthropogenic perturbations (Miller et al. 1989; Rahel 2002). Proliferation of nonindigenous species and extinction of na- tive species (Christie 1974; Kaufman 1992), habitat destruction (Benke 1990; Scott and Helfman 2001), and overfishing (Smith 1968; Jackson et al. 2001) are some of the many stressors that

*Corresponding author: jglonder@gmail.com

Received April 24, 2012; accepted November 23, 2012

Published online February 19, 2013 
have destabilized aquatic food webs. Ecosystem-based management is needed to ensure long-term sustainability of aquatic environments in rapidly changing ecosystems (Link 2002; Hilborn et al. 2003). Estimation of the diet composition of fishes, even for species without recreational or commercial value, is one of many data requirements for implementing ecosystem-based fishery management (Pitcher 2001; Francis et al. 2007). For example, quantitative analysis of diet has contributed to the parameterization of ecosystem and bioenergetics models (Christensen 1995; Hanson et al. 1997), the identification of fish recruitment bottlenecks via predation on larvae or eggs (Tyus and Saunders 2000; Richardson et al. 2011), and the estimation of diet overlap and competition among fishes (Winemiller 1989; Garrison and Link 2000a; Diana 2005).

Over the past century, food webs of the Laurentian Great Lakes (hereafter, Great Lakes) have been profoundly influenced by nonindigenous species (Wells and McLain 1973; Mills et al. 1993), and a new wave of nonnative species has invaded the lakes since the mid-1980s (Jude 2001; Vanderploeg et al. 2002). Round Goby Neogobius melanostomus were first discovered in 1990 in the St. Clair River (Jude et al. 1992) and now occur in all of the Great Lakes. They have been implicated in the recruitment failure of native Mottled Sculpin Cottus bairdii (Dubs and Corkum 1996; Janssen and Jude 2001) and may have competitive interactions with other nearshore native fishes (French and Jude 2001; Balshine et al. 2005; Bergstrom and Mensinger 2009). Consumption of fish eggs by Round Goby also has been observed (Roseman et al. 2006) and may limit recruitment of Lake Trout Salvelinus namaycush (Chotkowski and Marsden 1999; Fitzsimons et al. 2006) and Smallmouth Bass Micropterus dolomieu (Steinhart et al. 2004). During winter, Round Goby move offshore into deepwater benthic habitats (Miller 1986; Walsh et al. 2007), where they could conceivably compete with native fishes (i.e., Slimy Sculpin Cottus cognatus, Deepwater Sculpin Myoxocephalus thompsonii, and Bloater Coregonus hoyi) or consume the incubating eggs of native species. Unfortunately, the diets consumed by Round Goby, Slimy Sculpin, and Deepwater Sculpin during early winter and spring in Lake Michigan are unknown.

Ironically, diet overlap between Round Goby and native offshore sculpins could be alleviated by the proliferation of another invader, the quagga mussel Dreissena rostriformis, which now exists at high densities in offshore areas of Lake Michigan (Bunnell et al. 2009b; Nalepa et al. 2010), Lake Huron (Pothoven and Nalepa 2006), and Lake Ontario (Lozano 2011). Slimy Sculpin and Deepwater Sculpin lack the molariform pharyngeal teeth that allow larger Round Goby (those $>60 \mathrm{~mm} \mathrm{TL}$ ) to be effective predators of bivalves (French 1993; Ghedotti et al. 1995) even in offshore waters (Walsh et al. 2007). Concomitant with the expansion of Dreissena spp. has been the precipitous decline of the native amphipods Diporeia spp. (hereafter, Diporeia; Dermott 2001; Nalepa et al. 2009), which were historically the most important component of the diets for Slimy Sculpin and Deepwater Sculpin (Wells 1980; Brandt 1986b; Wojcik et al. 1986).
Declines in the fecundity of Bloaters (Bunnell et al. 2009a) and declines in the condition and energy density of Deepwater Sculpin (Madenjian et al. 2000; Hondorp et al. 2005; Pothoven et al. 2011) have been attributed to the loss of Diporeia.

The full extent to which these perturbations have affected the diets or population dynamics of native offshore fishes in the Great Lakes remains largely unknown. In Lake Michigan, for example, the biomass of Deepwater Sculpin and Bloaters (which support a commercial fishery) has reached near recordlow levels, whereas Slimy Sculpin biomass has increased to near record-high levels based on data spanning a 37-year time series (Madenjian et al. 2012). It is unclear whether egg predation or interspecific competition between Round Goby and native sculpins underlies these changing population dynamics. Like the Round Goby, the Slimy Sculpin and Deepwater Sculpin have been hypothesized to consume sufficient quantities of fish eggs to limit recruitment of other fish species (Luecke et al. 1990; Foote and Brown 1998), yet to our knowledge no studies have identified eggs in sculpin diets to the species level. Fish eggs in diets can be difficult to identify due to similar morphological characteristics among species or due to rapid digestion rates (Ahlstrom and Moser 1976; Hunter and Kimbrell 1980), but recent use of genetic techniques on digested stomach contents may help to overcome this problem (Rosel and Kocher 2002; Carreon-Martinez et al. 2011). Given that Slimy Sculpin, Deepwater Sculpin, and Round Goby in Lake Michigan exhibit spatial overlap with the incubating eggs of Deepwater Sculpin and Bloaters during winter and spring, predation on these eggs could explain the recent record-low biomass trends for both species.

We sought to evaluate (1) the potential for competition (through diet overlap) between native sculpins and Round Goby and (2) the extent of egg predation by all three benthivores. To that end, we examined the winter and spring diets of Slimy Sculpin, Deepwater Sculpin, and Round Goby collected in offshore waters of Lake Michigan. We evaluated whether variation in diet proportions of prey taxa for each benthivore species could be explained by year, day of year, site, or sampling depth. We hypothesized that diet overlap would occur between the two sculpin species but not between Round Goby and sculpin. Further, we hypothesized that Deepwater Sculpin eggs and Bloater eggs would be consumed by all three benthivore species but that Slimy Sculpin would consume higher proportions of Bloater eggs given that Bloater recruitment is inversely correlated with the biomass of adult Slimy Sculpin present at the time of Bloater egg incubation (D. B. Bunnell, unpublished data).

\section{METHODS}

Slimy Sculpin, Deepwater Sculpin, and Round Goby were sampled during January-May 2009 and 2010 using bottom trawls (5-10 min per trawl haul) towed at depths of 69$128 \mathrm{~m}$ at four Lake Michigan sites (Figure 1). A 13-m Yankee trawl was used to sample fish offshore of Frankfort, 


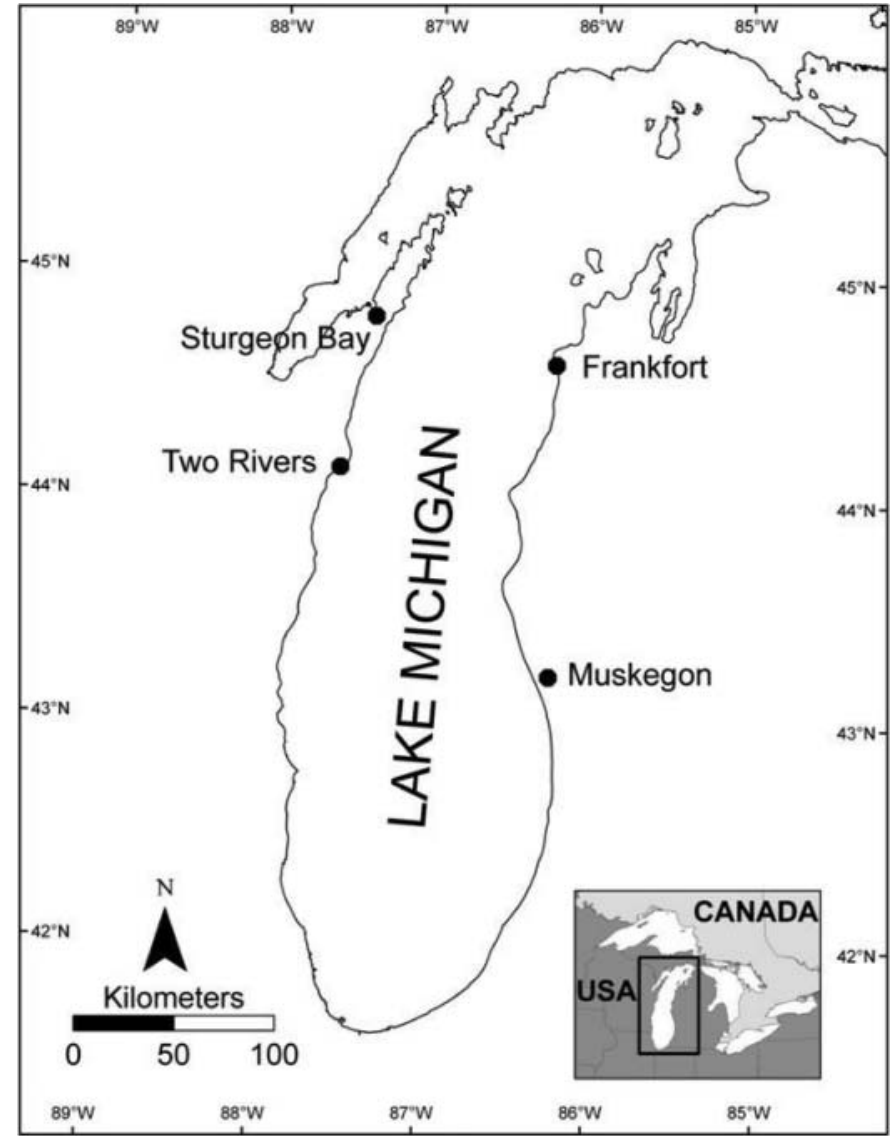

FIGURE 1. Sites in Lake Michigan where benthivores were sampled for diet analyses. Black circles represent the nearest port for offshore sampling locations.

Michigan $\left(44^{\circ} 30^{\prime} 39^{\prime \prime} \mathrm{N}, 86^{\circ} 20^{\prime} 18^{\prime \prime} \mathrm{W}\right)$, and Sturgeon Bay, Wisconsin $\left(44^{\circ} 42^{\prime} 1^{\prime \prime} \mathrm{N}, 87^{\circ} 7^{\prime} 31^{\prime \prime} \mathrm{W}\right)$. A $31-\mathrm{m}$ otter trawl was used to sample offshore of Two Rivers, Wisconsin $\left(44^{\circ} 17^{\prime} 57^{\prime \prime} \mathrm{N}\right.$, $\left.87^{\circ} 21^{\prime} 26^{\prime \prime} \mathrm{W}\right)$. An 8-m skate trawl, which fishes slightly higher off the bottom than conventional bottom trawls, was used to sample fish offshore of Muskegon, Michigan $\left(43^{\circ} 11^{\prime} 59^{\prime \prime} \mathrm{N}\right.$, $\left.86^{\circ} 34^{\prime} 11^{\prime \prime} \mathrm{W}\right)$. Exact locations of offshore collections varied slightly across the different depth strata sampled. After the fish collected in each trawl haul were sorted, all fish or 30-60 randomly subsampled specimens per species were immediately frozen. Because the sites were not all sampled monthly, the sampling design was unbalanced (Table 1).

Preserved fish were thawed, weighed (nearest $0.1 \mathrm{~g}$ ), and measured (TL, mm). Whole stomachs (esophagus to pyloric valve) of sculpins and the entire digestive tracts of Round Goby (esophagus to anus, since no similar valve exists) were excised and preserved in EDTA-enriched $95 \%$ ethanol to preserve genetic material. Under a dissecting microscope, excised contents from individuals were placed into a Ward counting wheel by using fine forceps and water. The stomach lining of sculpins was scraped into a separate watch glass to account for embedded prey.
Prey were classified to species, genus, or family and, when possible, life stage. We recorded the lengths of the first 10 individuals encountered for each prey type in each diet sample. For unmeasured prey, we applied the average prey length from all measured, intact prey of the same type across this data set. After all prey were identified and measured, dry weight values for each prey item were either calculated from published regressions or assumed from published descriptions (Table 2). Shell-free dry weights were used for dreissenids (French et al. 2007). More than 90 prey types (including different life stages, species, genera, and families) were encountered in benthivore diets, so we grouped the prey into 12 categories. The remaining rare prey taxa were combined into an additional category, "miscellaneous" (overall mean diet proportion $=0.02$ ). For each fish, diet proportions were calculated from summed dry weights of each taxonomic group. Because many invertebrates can be digested rapidly, we counted only specific body parts (such as the caudal rami of copepods, cephalic segments of Diporeia, eyes of Mysis spp. [hereafter, Mysis], and head capsules of chironomids) to limit double counting (Table 2).

Fish eggs that were found in diets were identified to species by using genetics because Slimy Sculpin, Deepwater Sculpin, and Bloater eggs that are spawned over winter and spring have similar morphology, coloring, and diameter (Rottiers 1965; Emery and Brown 1978; Rice et al. 1987; Geffen and Nash 1992; Owens and Noguchi 1998). As many as 10 whole, unpunctured eggs of similar sizes from individual diets were immediately preserved in EDTA-enriched $95 \%$ ethanol for subsequent genetic analysis. Confirmed tissue (fin clip) samples from Bloaters, Deepwater Sculpin, Slimy Sculpin, and Round Goby collected in Lake Michigan were used as DNA reference samples.

Species assignment of fish eggs in diets was conducted by using DNA barcoding, which examines approximately $700 \mathrm{bp}$ of the mitochondrial cytochrome $c$ oxidase I gene (COI; Hebert et al. 2003). We extracted DNA from the eggs by using the DNeasy Kit (Qiagen, Valencia, California), with one alteration to the published protocol: 3 milli-Anson units of proteinase $\mathrm{K}$ were added to ensure the complete digestion of eggs. Extracted DNA was examined for quality on $2 \%$ agarose gels and was quantified by using fluorometry. Amplification of DNA via PCR used primers VR1_t1 and VF2_t1 and followed the procedures outlined by Ivanova et al. (2007).

Analysis of restriction fragment length polymorphisms (RFLPs) of the COI region was used to identify the unknown eggs to species. Analysis of RFLPs allowed us to process each sample more quickly and cost effectively than would be possible with sequencing. Sequences from each species whose eggs we might encounter were selected from GenBank (www.ncbi.nlm. nih.gov/sites/gquery; Bloater: accession number EU523964.1; Deepwater Sculpin: EU524918.1; Slimy Sculpin: EU524520.1; Round Goby: EU524920.1). We then used RestrictionMapper version 3.0 (www.restrictionmapper.org) to find a restriction enzyme (RE) that would cut the COI region in all species of 
TABLE 1. Number of trawl hauls used to collect benthivores at each Lake Michigan site during each month and year of sampling. Range of depths sampled was 69-108 m (14 depths total) at Two Rivers, Wisconsin; 73-128 m (5 depths total) at Frankfort, Michigan; 73-128 m (5 depths total) at Sturgeon Bay, Wisconsin; and $90-107 \mathrm{~m}$ (3 depths total) at Muskegon, Michigan.

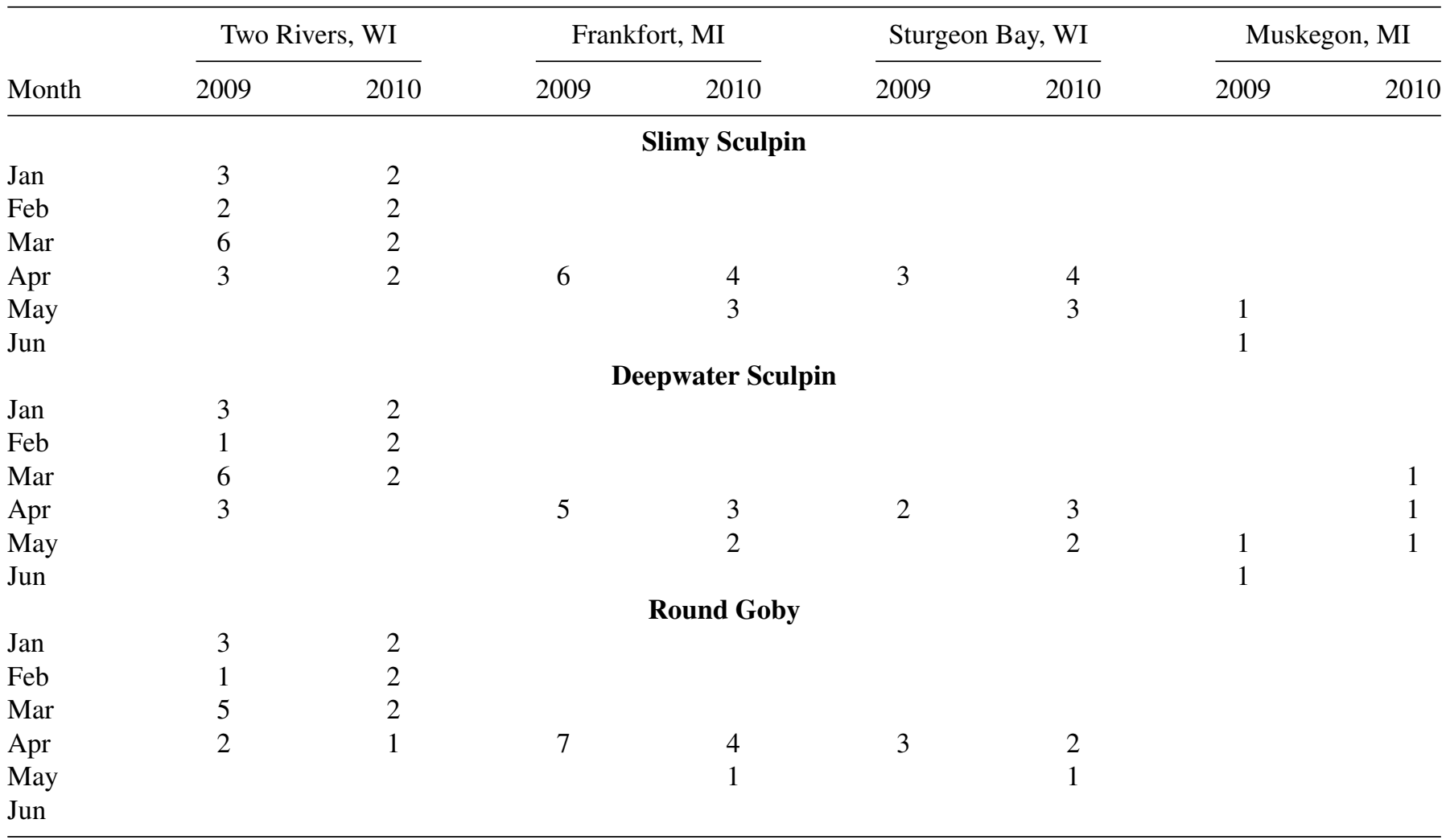

interest. Analysis of the COI sequences indicated that the RE HaeIII cut the COI fragment and produced a unique banding pattern among the four species. Restriction enzyme digests were performed in a $15-\mu \mathrm{L}$ reaction that included 90 units of the RE and the manufacturer's recommended buffer (New England BioLabs). Fragments of DNA were separated on $3.5 \%$ agarose gels that were stained with ethidium bromide and then photographed under ultraviolet light. Banding patterns of the known species were compared with those of the eggs to identify the species of each unknown egg from the diet.

Examples of each RFLP phenotype observed in the eggs were also sequenced to further confirm species identity, and PCR was performed as described above. Unincorporated nucleotides and primers were removed from the amplicon by using the QIAquick PCR Purification Kit (Qiagen), and gene sequences were determined from both strands on an Applied Biosystems Model 3730XL sequencer at the DNA Sequencing Core Facility, University of Michigan, Ann Arbor. Sequences were queried against those in GenBank (www.ncbi.nlm.nih.gov/nucleotide/) by using the BLAST search algorithm (Altschul et al. 1990) to determine the species.

The species identity of eggs not subjected to DNA analysis was assigned based on the proportions of eggs that were genetically identified in the diet contents of each individual fish. In cases where $100 \%$ of the eggs submitted for DNA analysis from an individual's diet were identified as belonging to one species, the remaining eggs were assigned to the same species (this occurred in $40 \%$ of samples). When DNA analysis revealed that multiple species were represented among the eggs in an individual's diet, the observed ratio of species was assigned to any remaining eggs in the diet (5\% of samples). When eggs were found but were too digested for DNA analysis (45\% of samples), the mean ratio estimated for fish of that benthivore species collected in the same trawl haul was applied to the unknown eggs. When ratios from the same predator species in the same trawl haul were unavailable, we applied a mean ratio from the same benthivore species collected either (1) at the nearest depth but on the same date and at the same site $(8 \%)$ or (2) at a different site but during the same month $(2 \%)$.

To explain variation in diets of Slimy Sculpin, Deepwater Sculpin, and Round Goby, we developed general linear models (GLMs). Model 1 examined the effect of the day of year on diet composition and used only diets from samples collected offshore of Two Rivers because that was the only site where sampling occurred in January-April (Table 1). Whether model 2 GLMs used data from all time periods or only April (the month when all sites were sampled) depended on the results from model 1 GLMs. Model 2 GLMs determined whether variation 
TABLE 2. Summary information for the 12 prey categories used in analyses of Lake Michigan benthivore diets.

\begin{tabular}{|c|c|c|c|c|c|}
\hline Prey category & Life stages & $\begin{array}{l}\text { Taxonomic } \\
\text { resolution }\end{array}$ & Identified from & Measurement & Sources \\
\hline Bivalves & Veliger to shelled & $\begin{array}{c}\text { Family to } \\
\text { species }\end{array}$ & $\begin{array}{l}\text { Visual, right } \\
\text { septum }\end{array}$ & Shell, septum & $\begin{array}{l}\text { Hillbricht-Ilkowska and } \\
\text { Stanczykowska 1969; Prejs } \\
\text { et al. 1990; Nalepa et al. } \\
2010\end{array}$ \\
\hline $\begin{array}{l}\text { Deepwater } \\
\text { Sculpin eggs }\end{array}$ & Egg, embryo & Species & Whole, DNA & Radius & Geffen and Nash 1992 \\
\hline Chironomids & Larva to adult & $\begin{array}{l}\text { Genus to } \\
\text { species }\end{array}$ & Head, mouth parts & $\begin{array}{l}\text { Length, head } \\
\text { width }\end{array}$ & Nalepa and Quigley 1980 \\
\hline Diporeia spp. & Adult & Species & Cephalic segment & Head to telson & Pothoven et al. 2001 \\
\hline Mysis spp. & Adult & Species & Eyeballs & Antennal scale & $\begin{array}{l}\text { Grossnickle and Beeton 1979; } \\
\text { Shea and Makarewicz } 1989\end{array}$ \\
\hline Fish remains & Unknown, adults & $\begin{array}{c}\text { Family to } \\
\text { species }\end{array}$ & Visual, cleithra & Length, weight & $\begin{array}{l}\text { J. G. Mychek-Londer, } \\
\text { unpublished data }\end{array}$ \\
\hline Ostracods & $\begin{array}{l}\text { Unknown, no } \\
\text { eggs }\end{array}$ & Class & Shells & Shell length & Nalepa and Quigley 1980 \\
\hline $\begin{array}{l}\text { Other } \\
\text { copepods }\end{array}$ & Nauplius to adult & $\begin{array}{c}\text { Family to } \\
\text { species }\end{array}$ & Rami, morphology & $\begin{array}{l}\text { Head to } \\
\text { urosome }\end{array}$ & $\begin{array}{l}\text { Pace and Orcutt } 1981 \\
\text { Hudson et al. } 2003\end{array}$ \\
\hline
\end{tabular}

in diet composition could be explained by spatial effects. In all model 2 GLMs, data from Slimy Sculpin collected at Muskegon during May and June were excluded because of low sample sizes $(N=3$ fish). Both models included year as a categorical variable and depth as a continuous variable. For the sampling unit, mean diet proportions (by dry weight) for all fish of a given benthivore species caught within the same trawl haul were used instead of individual fish diets (i.e., to avoid pseudoreplication). In each model, the number of individual diets sampled from each trawl haul was used as a weighting factor. For each GLM, we developed individual models for each predator species and the corresponding prey categories that constituted at least $90 \%$ of the predator species' overall diet by dry weight. This required five taxonomic categories for Slimy Sculpin, four categories for Deepwater Sculpin, and three categories for Round Goby. Bonferroni adjustments to significance levels were made based on the number of prey categories analyzed for a given benthivore species (e.g., for four prey categories, $\alpha=0.05 / 4=0.0125$ ).
To determine whether the prey proportions used in GLMs were influenced by predator size, the TL of each individual fish caught at a site was regressed against the corresponding diet proportion (by dry weight) of each important prey taxon. Because no visual patterns emerged and all $r^{2}$ values were low $(<0.02)$, the effects of predator TL on diet proportions were ignored.

The diet overlap between each pair of benthivore species at each site was calculated by using the mean taxonomic proportions (by dry weight; pooling across all dates and depths for each benthivore species at each site) for all 13 prey categories via the method of Schoener (1970),

$$
D_{x, y}=1-0.5\left(\sum_{i=1}^{n}\left|P_{i x}-P_{i y}\right|\right)
$$

where $D_{x, y}=$ Schoener's overlap index between species $x$ and species $y ; P_{i x}=$ proportion of food category $i$ used by species 
$x$; and $P_{i y}=$ proportion of food resource $i$ used by species $y$. Values of 0.60 or higher indicated significant overlap and possible competition if resources were limiting (Martin 1984).

\section{RESULTS}

In total, 2,266 fish with nonempty stomachs were used in analyses (Slimy Sculpin: $N=1,015$; Deepwater Sculpin: $N=699$; Round Goby: $N=552$; for more details, see Table 3 of Londer 2011). Pooling across all sites, Slimy Sculpin consumed mainly Mysis, Limnocalanus macrurus, Diporeia, and chironomids (Figure 2). Deepwater Sculpin consumed mostly Mysis and Diporeia; Round Goby consumed mostly bivalves, Mysis, and ostracods. Of the bivalves found in Round Goby diets, $72 \%$ were quagga mussels, $24 \%$ were unidentified dreissenids, $2 \%$ were zebra mussels Dreissena polymorpha, and 2\% were other bivalves. Diporeia was not found in the diets of any benthivore species sampled offshore of Frankfort and Muskegon (Table 3).

Of the 522 fish eggs used for DNA analysis, 392 were identified as Deepwater Sculpin, 88 were identified as Bloaters, 34 were identified as Burbot Lota lota, 4 were identified as Slimy Sculpin, and 4 were identified as Lake Whitefish Coregonus clupeaformis. Species identification of Burbot and Lake Whitefish eggs was based on sequencing results. After assigning species to eggs that were not analyzed for their DNA, we estimated that the total number of eggs consumed by all benthivores sampled was 2,456 Deepwater Sculpin eggs, 894 Burbot eggs, 364 Bloater eggs, 14 Slimy Sculpin eggs, and 4 Lake Whitefish eggs. All Burbot eggs were identified from the diets of three Slimy Sculpin that were sampled in a single trawl haul conducted offshore of Frankfort at 128-m depth on 20 April 2010. All Lake Whitefish eggs were eaten by two Deepwater Sculpin that were taken offshore of Muskegon (at 100-m depth) on 17 April 2009 and offshore of Sturgeon Bay (128-m depth) on 1 May 2009. All Slimy Sculpin eggs were identified from the diets of four Slimy Sculpin sampled at 85-100-m depths offshore of Two Rivers, Sturgeon Bay, and Frankfort during February, April, and May.

Deepwater Sculpin eggs were the most common eggs in benthivore diets and occurred at all four sites during January-May (Table 4). Of the eggs that were identified and assigned as Deepwater Sculpin, $56 \%$ were cannibalized, $31 \%$ were consumed by Slimy Sculpin, and 13\% were consumed by Round Goby. Slimy Sculpin offshore of Frankfort and Deepwater Sculpin offshore of Two Rivers, Sturgeon Bay, and Muskegon ate relatively high proportions of Deepwater Sculpin eggs (0.03-0.06) at a frequency of occurrence ranging from $11 \%$ to $25 \%$ across many depths (Tables 3, 4). For some individual predators, a surprisingly high number of Deepwater Sculpin eggs were found in the diet. For example, 10 Slimy Sculpin each contained more than 22 eggs in their stomachs, and three Slimy Sculpin contained more than 90 eggs each. Furthermore, 17 Deepwater Sculpin each contained more than 20 Deepwater Sculpin eggs, and eight Deepwater Sculpin contained more than 70 eggs each. Finally,

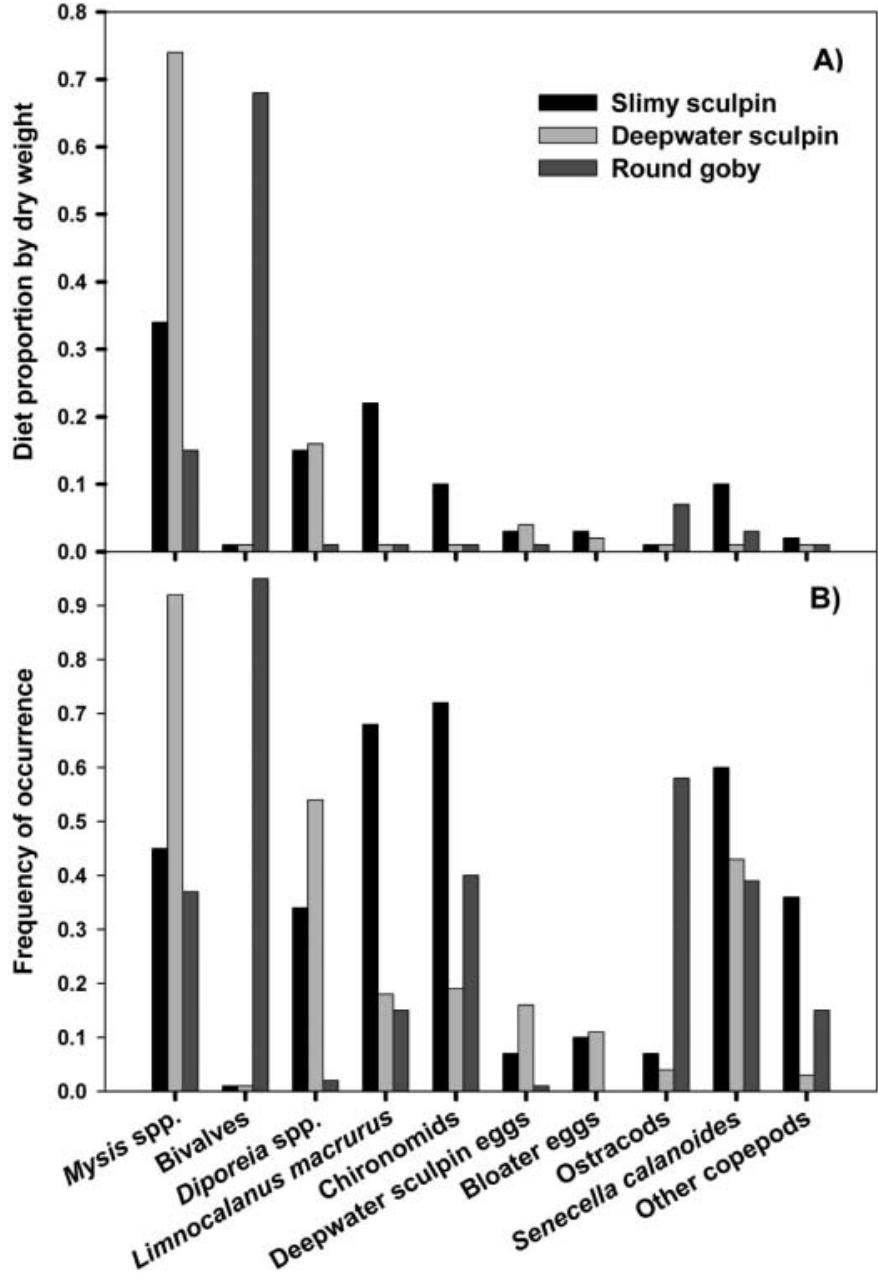

FIGURE 2. Mean (A) diet proportions and (B) frequency of occurrence of prey types in the diets of Slimy Sculpin, Deepwater Sculpin, and Round Goby sampled in Lake Michigan during January-June 2009-2010. Data were pooled for all individuals of a given predator species across all stations, depths, and dates. Slimy Sculpin samples collected during May and June at Muskegon are excluded because of low sample sizes ( $N=3$ fish).

three Round Goby each contained more than 61 Deepwater Sculpin eggs in their digestive systems.

Bloater eggs were found in benthivore diets at all four sites during February-May; $62 \%$ of the Bloater eggs were consumed by Slimy Sculpin, 34\% were consumed by Deepwater Sculpin, and $4 \%$ were consumed by Round Goby (Table 4). Slimy Sculpin sampled offshore of Frankfort and Deepwater Sculpin collected offshore of Muskegon ate relatively high proportions of Bloater eggs (0.04-0.07) at a frequency of occurrence ranging from $21 \%$ to $23 \%$ (Table 3 ) across many depths (Table 4). The maximum number of Bloater eggs observed in the diet of one individual predator was 14 eggs in a Slimy Sculpin and 10 eggs in a Deepwater Sculpin.

The model 1 GLMs indicated that day of year did not influence the mean diet proportions of any prey taxon examined for the three benthivore species offshore of Two Rivers. 
TABLE 3. Diet proportion (by dry weight) and percent frequency of occurrence (in parentheses) of prey taxa consumed by benthivore species (SS $=$ Slimy Sculpin; DWS = Deepwater Sculpin; RG = Round Goby) at each site in Lake Michigan, 2009-2010. Summed proportions may not equal 1.0 because of rounding and because two categories (cladocerans and miscellaneous) are excluded.

\begin{tabular}{|c|c|c|c|c|c|c|c|c|c|c|}
\hline Taxon & \multicolumn{3}{|c|}{ Frankfort, MI } & $\frac{\text { Muskegon, MI }}{\text { DWS }}$ & \multicolumn{3}{|c|}{ Two Rivers, WI } & \multicolumn{3}{|c|}{ Sturgeon Bay, WI } \\
\hline Bivalves & $<0.01(4)$ & $<0.01(8)$ & $0.58(96)$ & $<0.01(8)$ & $<0.01$ (3) & $<0.01(5)$ & $0.83(95)$ & $<0.01(6)$ & $<0.01(7)$ & $0.62(95)$ \\
\hline Chironomids & $0.05(53)$ & $<0.01(21)$ & $<0.01(44)$ & $<0.01(8)$ & $0.10(79)$ & $<0.01(7)$ & $0.01(17)$ & $0.15(83)$ & $0.01(41)$ & $0.01(59)$ \\
\hline $\begin{array}{l}\text { Deepwater } \\
\text { Sculpin eggs }\end{array}$ & $0.03(11)$ & $0.01(4)$ & $0.01(1)$ & $0.05(21)$ & $0.01(2)$ & $0.06(13)$ & $0.02(3)$ & $0.03(8)$ & $0.05(24)$ & $<0.01(1)$ \\
\hline $\begin{array}{l}\text { Limnocalanus } \\
\text { macrurus }\end{array}$ & $0.09(58)$ & $<0.01(20)$ & $<0.01(10)$ & $0.01(17)$ & $0.48(90)$ & $0.03(20)$ & $0.02(26)$ & $0.09(56)$ & $<0.01(16)$ & $<0.01(8)$ \\
\hline Mysis spp. & $0.58(72)$ & $0.97(100)$ & $0.33(62)$ & $0.88(95)$ & $0.19(26)$ & $0.61(82)$ & $0.03(5)$ & $0.24(37)$ & $0.50(90)$ & $0.10(15)$ \\
\hline Ostracods & $<0.01(8)$ & $<0.01(11)$ & $0.02(59)$ & $<0.01$ & $0.01(9)$ & $<0.01$ & $0.04(44)$ & $<0.01(3)$ & $<0.01(1)$ & $0.14(71)$ \\
\hline $\begin{array}{l}\text { Senecella } \\
\quad \text { calanoides }\end{array}$ & $0.13(79)$ & $0.02(80)$ & $0.05(72)$ & $0.01(17)$ & $0.05(43)$ & $0.01(23)$ & $0.01(9)$ & $0.11(56)$ & $0.01(53)$ & $0.03(35)$ \\
\hline
\end{tabular}

TABLE 4. Summary of species identifications for eggs that were consumed by benthivores $(\mathrm{SS}=$ Slimy Sculpin; DWS $=$ Deepwater Sculpin; RG $=$ Round Goby) collected from Lake Michigan, 2009-2010 (sites: TR = Two Rivers, Wisconsin; FF = Frankfort, Michigan; MSK = Muskegon, Michigan; STB = Sturgeon Bay, Wisconsin). See Methods for descriptions of egg identification and assignment. Note that SS collected at MSK included only two fish, whereas the sample size for all other month $\times$ port combinations always exceeded 64 for SS, 23 for DWS, and 16 for RG.

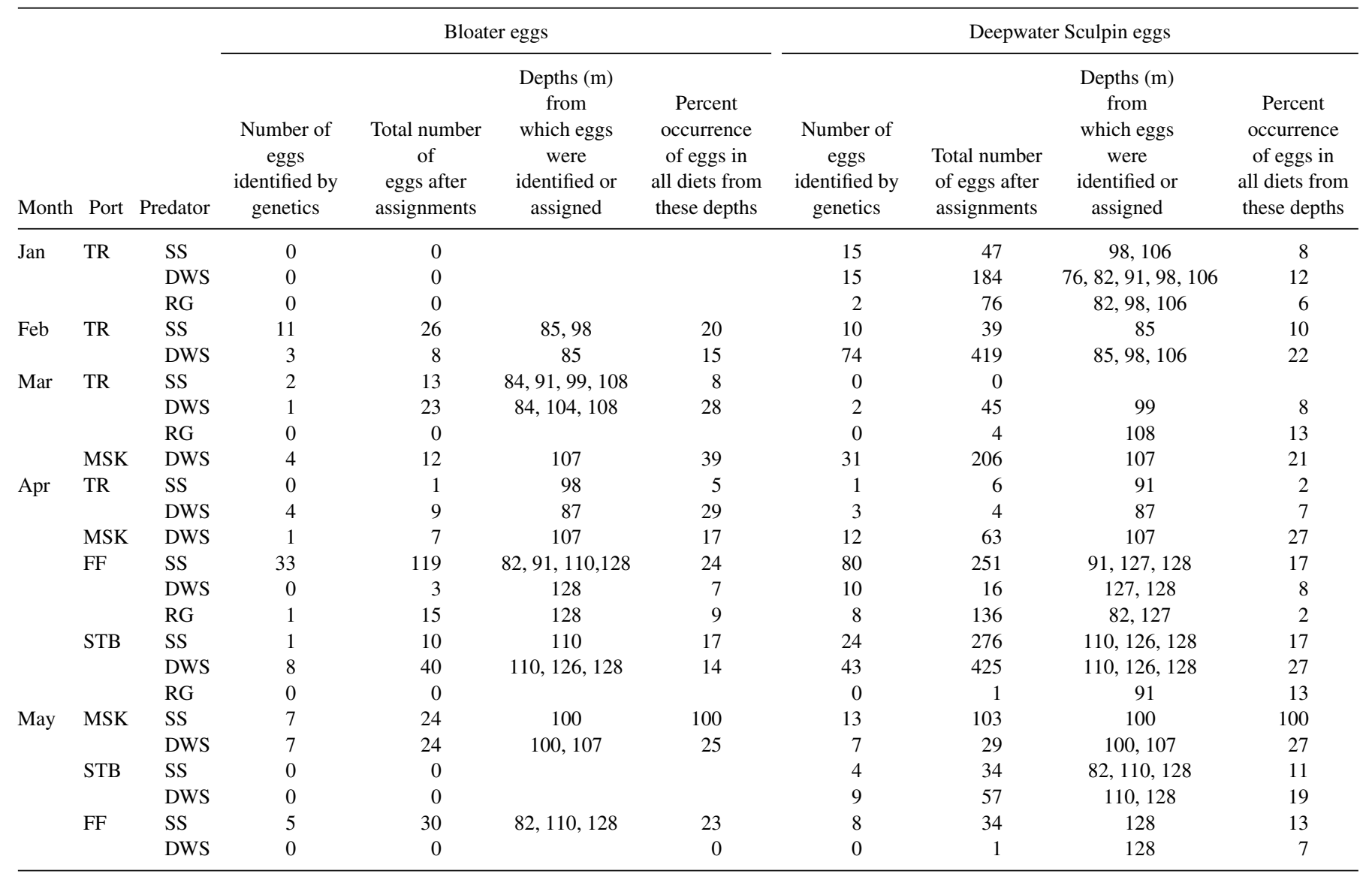


TABLE 5. Results ( $F$ - and $P$-values) of general linear models explaining variation in diet proportions (by dry weight) for a given prey taxonomic category consumed by three benthivore species collected in Lake Michigan during 2009-2010. The sampling unit in these analyses was the mean diet proportion of a given prey type for all individuals of a predator species that were caught within the same trawl haul. Model 1 used only data from benthivore species caught at Two Rivers, Wisconsin; model 2 used data from benthivores caught at all four sites. Significant $P$-values that were less than the Bonferroni-adjusted $\alpha$ are shown in bold italics.

\begin{tabular}{|c|c|c|c|c|c|c|c|}
\hline Prey type & Predator species & \multicolumn{3}{|c|}{ Model 1} & \multicolumn{3}{|c|}{ Model 2} \\
\hline Bivalves & Round Goby & $\begin{aligned} F_{1,14} & =0.66 \\
P & =0.4316\end{aligned}$ & $\begin{aligned} F_{1,14} & =0.03 \\
P & =0.8753\end{aligned}$ & $\begin{aligned} F_{1,14} & =2.61 \\
P & =0.1283\end{aligned}$ & $\begin{aligned} F_{2,31} & =4.34 \\
P & =0.0219\end{aligned}$ & $\begin{aligned} F_{1,31} & =2.74 \\
P & =0.1080\end{aligned}$ & $\begin{array}{r}F_{1,31}=17.33 \\
\boldsymbol{P}=\mathbf{0 . 0 0 0 2}\end{array}$ \\
\hline Chironomids & Slimy Sculpin & $\begin{aligned} F_{1,18} & =6.61 \\
P & =0.0192\end{aligned}$ & $\begin{aligned} F_{1,18} & =0.04 \\
P & =0.8406\end{aligned}$ & $\begin{aligned} F_{1,18} & =1.80 \\
P & =0.1963\end{aligned}$ & $\begin{aligned} F_{2,40} & =3.34 \\
P & =0.0403\end{aligned}$ & $\begin{aligned} F_{1,40} & =4.62 \\
P & =0.0878\end{aligned}$ & $\begin{aligned} F_{1,40} & =3.52 \\
P & =0.0677\end{aligned}$ \\
\hline Deepwater Sculpin eggs & Deepwater Sculpin & $\begin{aligned} F_{1,15} & =0.41 \\
P & =0.5314\end{aligned}$ & $\begin{aligned} F_{1,15} & =1.26 \\
P & =0.2800\end{aligned}$ & $\begin{aligned} F_{1,15} & =3.70 \\
P & =0.0738\end{aligned}$ & $\begin{aligned} F_{3,34} & =2.23 \\
P & =0.1021\end{aligned}$ & $\begin{aligned} F_{1,34} & =0.64 \\
P & =0.4297\end{aligned}$ & $\begin{aligned} F_{1,34} & =2.54 \\
P & =0.1203\end{aligned}$ \\
\hline Diporeia spp. & Deepwater Sculpin & $\begin{aligned} F_{1,15} & =5.56 \\
P & =0.0324\end{aligned}$ & $\begin{array}{r}F_{1,15}=11.69 \\
\boldsymbol{P}=\mathbf{0 . 0 0 3 8}\end{array}$ & $\begin{aligned} F_{1,15} & =0.00 \\
P & =0.9606\end{aligned}$ & $\begin{array}{r}F_{3,34}=12.55 \\
\boldsymbol{P}<\boldsymbol{0 . 0 0 0 1}\end{array}$ & $\begin{aligned} F_{1,34} & =5.59 \\
P & =0.0239\end{aligned}$ & $\begin{aligned} F_{1,34} & =1.42 \\
P & =0.2424\end{aligned}$ \\
\hline \multirow[t]{2}{*}{ Limnocalanus macrurus } & Slimy Sculpin & $\begin{aligned} F_{1,18} & =1.70 \\
P & =0.2092\end{aligned}$ & $\begin{aligned} F_{1,18} & =1.76 \\
P & =0.2016\end{aligned}$ & $\begin{aligned} F_{1,18} & =2.11 \\
P & =0.1637\end{aligned}$ & $\begin{aligned} F_{2,40} & =15.86 \\
\boldsymbol{P} & <\boldsymbol{0 . 0 0 0 1}\end{aligned}$ & $\begin{aligned} F_{1,40} & =3.62 \\
P & =0.0642\end{aligned}$ & $\begin{aligned} F_{1,40} & =5.27 \\
P & =0.0269\end{aligned}$ \\
\hline & Deepwater Sculpin & $\begin{aligned} F_{1,15} & =1.19 \\
P & =0.2934\end{aligned}$ & $\begin{aligned} F_{1,15} & =1.75 \\
P & =0.2055\end{aligned}$ & $\begin{aligned} F_{1,15} & =3.52 \\
P & =0.0803\end{aligned}$ & $\begin{aligned} F_{3,34} & =0.32 \\
P & =0.5743\end{aligned}$ & $\begin{aligned} F_{1,34} & =0.64 \\
P & =0.4297\end{aligned}$ & $\begin{aligned} F_{1,34} & =1.39 \\
P & =0.2473\end{aligned}$ \\
\hline Mysis spp. & Round Goby & $\begin{aligned} F_{1,14} & =0.38 \\
P & =0.5489\end{aligned}$ & $\begin{aligned} F_{1,14} & =2.91 \\
P & =0.1102\end{aligned}$ & $\begin{aligned} F_{1,14} & =0.53 \\
P & =0.4786\end{aligned}$ & $\begin{array}{r}F_{2,31}=14.81 \\
\boldsymbol{P}=\mathbf{0 . 0 0 0 1}\end{array}$ & $\begin{aligned} F_{1,31} & =3.65 \\
P & =0.0650\end{aligned}$ & $\begin{aligned} F_{1,31} & =9.52 \\
\boldsymbol{P} & =\mathbf{0 . 0 0 5 2}\end{aligned}$ \\
\hline Ostracods & Round Goby & $\begin{aligned} F_{1,14} & =0.87 \\
P & =0.3654\end{aligned}$ & $\begin{aligned} F_{1,14} & =2.07 \\
P & =0.1719\end{aligned}$ & $\begin{aligned} F_{1,14} & =0.16 \\
P & =0.6932\end{aligned}$ & $\begin{aligned} F_{2,31} & =4.50 \\
P & =0.0192\end{aligned}$ & $\begin{aligned} F_{1,31} & =4.19 \\
P & =0.0492\end{aligned}$ & $\begin{aligned} F_{1,31} & =3.46 \\
P & =0.0726\end{aligned}$ \\
\hline Senecella calanoides & Slimy Sculpin & $\begin{aligned} F_{1,18} & =1.88 \\
P & =0.1871\end{aligned}$ & $\begin{aligned} F_{1,18} & =1.38 \\
P & =0.2548\end{aligned}$ & $\begin{aligned} F_{1,18} & =7.11 \\
P & =0.0157\end{aligned}$ & $\begin{aligned} F_{2,40} & =4.68 \\
P & =0.0149\end{aligned}$ & $\begin{aligned} F_{1,40} & =1.80 \\
P & =0.1879\end{aligned}$ & $\begin{aligned} F_{1,40} & =0.67 \\
P & =0.4174\end{aligned}$ \\
\hline
\end{tabular}

Additionally, the year of sampling was never significant, and depth was significant only for Deepwater Sculpin consuming Diporeia (Table 5). Because day of year was not significant in model 1 GLMs, the model 2 GLMs used diets from all sites and dates sampled. Of the 12 model 2 GLMs that were run, six revealed that significant variation in mean diet proportion was explained by site. In particular, the proportion of Mysis varied among sites for all three benthivore species, the proportion of Diporeia varied among sites for each sculpin species, and the proportion of bivalves varied among sites for Round Goby. The proportions of Mysis and bivalves in the diets of Round Goby also differed between years. Depth was not an important explanatory variable for any model 2 GLM (Table 5).

As hypothesized, diet overlap between Round Goby and either sculpin species was not significant $(D \leq 0.39)$. Significant diet overlap occurred between the two sculpin species offshore of Frankfort $(D=0.62)$ and Sturgeon Bay $(D=0.62)$ but not offshore of Two Rivers $(D=0.39)$. At Frankfort, the diets of Deepwater Sculpin and Slimy Sculpin were strongly associated with Mysis. Besides Mysis, prey taxa that were important in the diets of Slimy Sculpin at this site included Senecella calanoides, L. macrurus, and chironomids. At Sturgeon Bay, Deepwater Sculpin consumed higher proportions of Mysis and Diporeia than did Slimy Sculpin, whereas Slimy Sculpin con- sumed higher proportions of $S$. calanoides, L. macrurus, and chironomids. At Two Rivers, the lack of diet overlap between Slimy Sculpin and Deepwater Sculpin was the result of (1) Slimy Sculpin consuming higher diet proportions of L. macrurus and (2) Deepwater Sculpin consuming higher proportions of Mysis and Diporeia.

\section{DISCUSSION}

These descriptions of diet composition for Deepwater Sculpin, Slimy Sculpin, and Round Goby provide valuable data to inform ecosystem-based management by filling data gaps for ecosystem and recruitment modeling efforts (Zimmerman and Krueger 2009). Our results clearly indicate that sculpin and Round Goby diets varied by site, likely due to site-specific differences in prey availability. Another important finding was that Round Goby appeared to have minimal impacts on offshore native fishes in Lake Michigan, as the diets of Round Goby were different from those of sculpins and the occurrence of fish eggs in the diet was 1.6\%. However, if Round Goby populations increase and maintain their consumption of Mysis (which averaged 0.15 of their diet by dry weight proportion) while native sculpins and other native fishes increase their reliance on Mysis in response to declines in Diporeia (Pothoven and Madenjian 2008; Hondorp et al. 2011), increased top-down 
pressure on Mysis could ensue. Further, although frequencies of occurrence and diet proportions of fish eggs in sculpin diets seemed comparable to observations from previous studies, we were able to identify eggs to species, and this new knowledge can be used to evaluate whether egg predation is a bottleneck in the recruitment dynamics of native species. Lastly, egg predation may be more important today than in the past because the biomass (and therefore egg production) of Bloaters and Deepwater Sculpin appears to be near record-low levels, while Slimy Sculpin biomass is very high relative to historic levels. As a result, even if sculpins consume a small proportion of eggs, this could have a disproportionate impact upon recruitment of Bloaters and Deepwater Sculpin.

An understanding of the relative contribution of spatial and temporal differences in diet composition is important given that most ecosystem models require an "average" annual diet for each prey species (e.g., Christensen and Walters 2004). Benthivore diet studies in large aquatic ecosystems have indicated that both regional and temporal variation can be important to incorporate (e.g., Garrison and Link 2000b; Byron and Link 2010). Our GLM results revealed that benthivore diets varied more across sites than by day of year, which was consistent with previous reports that spatial variability in sculpin diets was likely driven by differential availability of prey species across sites (Hondorp et al. 2005; O'Brien et al. 2009). Furthermore, other studies that have sampled sculpin diets across multiple seasons have revealed minimal variation in diet composition except for higher occurrences of fish eggs in the diets of Slimy Sculpin during spring and autumn and in the diets of Deepwater Sculpin during autumn (Wells 1980; Kraft and Kitchell 1986; Wojcik et al. 1986). Our work suggests that to best characterize benthivore diets so as to inform lakewide ecosystem models, future studies should emphasize broad spatial coverage over intense temporal coverage at a limited number of sites unless the goal is to capture seasonal pulses of species-specific fish eggs.

Although the day of year did not influence diet composition, we did detect a year effect on the diet proportions of Mysis and bivalves consumed by Round Goby. Because only 2 years were sampled, determining whether the year effect was random variation or an emerging pattern with ecological implications is difficult. Schaeffer et al. (2005) hypothesized that the difference in Round Goby diets between autumn 2001 and 2002 in Lake Huron was the result of changes in prey availability. Our results revealed that Round Goby consumed more dreissenids and fewer Mysis in 2010 than in 2009. Increases in quagga mussel availability from 2009 to 2010 in offshore Lake Michigan seem logical based on trends observed through 2008 (Bunnell et al. 2009b; Nalepa et al. 2009); however, lakewide trends in $M y$ sis densities demonstrated no strong pattern between 2006 and 2011 (D. M. Warner, U.S. Geological Survey [USGS], personal communication). Nonetheless, Round Goby exhibited greater interannual variability in diets than did native sculpins, and this plasticity in diets is relatively common for nonindigenous fish exploiting new habitats (García-Berthou 2002; Vila-Gispert et al. 2007).

While we did not detect significant interannual variation in sculpin diets, comparison of our results with the results of previous studies indicates an overall reduction in the importance of Diporeia as a prey resource. French et al. (2010) found that the frequency of occurrence of Diporeia was $100 \%$ in Slimy Sculpin sampled from depths greater than $55 \mathrm{~m}$ offshore of both Frankfort and Sturgeon Bay in 2003. By 2009-2010, Diporeia was never found in the diets of sculpins sampled offshore of Frankfort, and this taxon's frequency of occurrence was only $46 \%$ in the diets of Slimy Sculpin offshore of Sturgeon Bay. Furthermore, in our study, Diporeia was never found in the diets of sculpins collected offshore of Muskegon, whereas in 2000-2001 Diporeia constituted 0.66 of the Slimy Sculpin diet and 0.45 of the Deepwater Sculpin diet at this site (Hondorp et al. 2005). The proportion of Diporeia in sculpin diets in the present study also was markedly lower than the proportions reported from studies that were completed prior to the invasions of Dreissena spp. and the concomitant decline of Diporeia (e.g., Wells 1980; Kraft and Kitchell 1986; Wojcik et al. 1986). We note, however, that Diporeia remained a component of the diets of sculpins at Two Rivers and Sturgeon Bay, a result that generally agrees with observations by Nalepa et al. (2009) that Diporeia densities are higher on the western side of Lake Michigan.

Previous studies have identified diet overlap between Slimy Sculpin and Deepwater Sculpin (Brandt 1986a; Davis et al. 2007), and we also identified overlap for these two species offshore of Frankfort (due to Mysis predominance) and Sturgeon Bay (due to predominance of Mysis and Diporeia). Conversely, diet overlap between the sculpins did not occur at Two Rivers because the Slimy Sculpin diet was dominated by calanoid copepods, while the Deepwater Sculpin diet was dominated by $D i$ poreia and Mysis. Whereas Deepwater Sculpin replaced Diporeia mainly with Mysis, Slimy Sculpin diversified their diet with other prey. For example, the chironomid proportion in the diets of Slimy Sculpin was as much as 0.15 , similar to the results of Owens and Dittman (2003) and Hondorp et al. (2011), who demonstrated positive selection for chironomids after the decline of Diporeia. Slimy Sculpin also may be taking advantage of prey that appear to be increasing in abundance, as the copepod $L$. macrurus had a $68 \%$ frequency of occurrence in their diets, while previous studies have never mentioned L. macrurus as a prey species (Wells 1980; Brandt 1986b; Kraft and Kitchell 1986; Owens and Dittman 2003; Hondorp et al. 2011). Correspondingly, recent studies have reported increasing densities of L. macrurus (Barbiero et al. 2009; Vanderploeg et al. 2012) in Lake Michigan. Comparatively, in Deepwater Sculpin diets, chironomids and $L$. macrurus occurred at frequencies of only up to $21 \%$ at any sampled port. Thus, diet overlap between Slimy Sculpin and Deepwater Sculpin could decrease in the future if Slimy Sculpin continue to diversify their diets in response to the decline of Diporeia while Deepwater Sculpin increase their reliance on Mysis. 
As hypothesized, diet overlap between Round Goby and either of the sculpin species was not observed because the Round Goby diets were dominated by bivalves (mostly quagga mussels). Dominance of dreissenids in Round Goby diets is also common in nearshore habitats (Ray and Corkum 1997; French and Jude 2001). Other important prey types consumed by Round Goby included Mysis offshore of Frankfort (dry weight proportion $=0.33$; frequency of occurrence $=62 \%$ ) and ostracods offshore of Sturgeon Bay $(0.14 ; 71 \%)$. Similarly high frequencies of occurrence of Mysis and ostracods were observed in diets of Round Goby collected during April in Lake Ontario at 95-m depth (Walsh et al. 2007) and during October in Lake Huron at 55-73-m depths (Schaeffer et al. 2005). We suspect that as long as quagga mussels are abundantly available to Round Goby in the Great Lakes, diet overlap between Round Goby and the two sculpin species will remain low.

Few diet studies have identified eggs to the species level, despite the fact that egg predation has been hypothesized to limit recruitment of several freshwater and marine species (Luecke et al. 1990; Köster and Möllmann 2000). Previous studies of Lake Michigan have reported that sculpins consumed fish eggs during spring, summer, and autumn, and those eggs were speculated to be the eggs of Bloaters or Deepwater Sculpin (Wells 1980; Hondorp et al. 2011). We took advantage of genetic techniques to determine that the Deepwater Sculpin was the species most commonly represented among eggs consumed by the three benthivore species. Most Deepwater Sculpin eggs were cannibalized (55\%), whereas Slimy Sculpin (31\%) and Round Goby (14\%) consumed the eggs in smaller percentages. Slimy Sculpin were the most frequent predators of Bloater eggs, consistent with our hypothesis that was based on an inverse relationship between Slimy Sculpin and Bloater recruitment. The potential importance of egg predation in creating bottlenecks to Deepwater Sculpin and Bloater recruitment should be explored in future modeling efforts, as it may have implications for the recovery or possible re-introduction of these native species to Great Lakes sites where they are either extirpated or only exist as remnant stocks (Roseman et al. 1998; Lantry et al. 2007; Zimmerman and Krueger 2009).

A bias that could have influenced our diet composition results was that the various prey types are not digested at equal rates. For example, bivalve shells (Prejs et al. 1990; French 1993) and chitinous chironomid heads (Hershey and McDonald 1985) may be resistant to digestion, thus resulting in diet proportions that are biased high for these taxa. Conversely, we were concerned that the number of fish eggs in the diets would be underestimated because eggs could be digested more quickly (Daan et al. 1985). However, our own feeding experiments revealed that fish eggs could remain identifiable for up to 3-5 d in the stomachs of Slimy Sculpin and Deepwater Sculpin held at a temperature of $4.5^{\circ} \mathrm{C}$ (J. G. Mychek-Londer, unpublished data).

Managers are becoming increasingly cognizant of the need to move away from single-species management and toward multispecies or even ecosystem-based fishery management (Pikitch et al. 2004). Diet information, especially where data gaps exist, can reveal how multispecies interactions influence population dynamics (Link et al. 2002, 2008). In this paper, we reported the winter and spring diets of benthivores in Lake Michigan, which had not been previously described. These data will be used to support several ecosystem models (currently in development) that will allow Lake Michigan managers to explore different scenarios of piscivore stocking or nutrient inputs. Our results also indicate that interspecific competition between nonindigenous Round Goby and native sculpins was unlikely, but our novel, species-level identification of eggs in benthivore diets revealed that egg predation by native sculpins (and, to a lesser extent, Round Goby) could be influencing the population dynamics of Deepwater Sculpin and Bloaters. As a result, future models to understand or forecast the population dynamics of these species should adopt a multispecies approach to account for the egg predation results presented here.

\section{ACKNOWLEDGMENTS}

Funding for this research was provided by the Great Lakes Fishery Commission and by the USGS Great Lakes Science Center. We appreciate assistance provided by Vincent Belill, Mark Rogers, Kevin Keeler, Betsy Puchala, Greg Jacobs, Lynn Ogilvie, Bruce Davis, Dave Bennion, and Barbara Diana. We thank the dedicated crews of the RV Grayling and RV Sturgeon as well as the Susie Q Commercial Fishery staff for their assistance in fish collection during winter and spring. We also thank Steven Pothoven for providing sculpins from Muskegon. This article is Contribution 1730 of the U.S. Geological Survey Great Lakes Science Center.

\section{REFERENCES}

Ahlstrom, E. H., and H. G. Moser. 1976. Eggs and larvae of fishes and their role in systematic investigations and in fisheries. Revue des Travaux de l'Institut des Pêches Maritimes 40(3/4):379-398.

Altschul, S. F., W. Gish, W. Miller, E. W. Myers, and D. J. Lipman. 1990. Basic local alignment search tool. Journal of Molecular Biology 215:403-410.

Andrew, T. E., and A. Herzig. 1984. The respiration rate of the resting eggs of Leptodora kindti (Focke 1844) and Bythotrephes longimanus Leydig 1860 (Crustacea, Cladocera) at environmentally encountered temperatures. Oecologia 64:241-244.

Balshine, S., A. Verma, V. Chant, and T. Theysmeyer. 2005. Competitive interactions between Round Gobies and Logperch. Journal of Great Lakes Research 31:68-77.

Barbiero, R. P., D. B. Bunnell, D. C. Rockwell, and M. L. Tuchman. 2009. Recent increases in the large glacial-relict calanoid Limnocalanus macrurus in Lake Michigan. Journal of Great Lakes Research 35:285-292.

Benke, A. C. 1990. A perspective on America's vanishing streams. Journal of the North American Benthological Society 9:77-88.

Bergstrom, M. A., and A. F. Mensinger. 2009. Interspecific resource competition between the invasive Round Goby and three native species: Logperch, Slimy Sculpin, and Spoonhead Sculpin. Transactions of the American Fisheries Society 138:1009-1017.

Bottrell, H. H., A. Duncan, Z. M. Gliwicz, E. Grygierek, A. Herzig, A. HillbrichtIlkowska, H. Kurasawa, P. Larsson, and T. Weglenska. 1976. A review of some problems in zooplankton production studies. Norwegian Journal of Zoology 24:419-456.

Brandt, S. B. 1986a. Disappearance of the Deepwater Sculpin (Myoxocephalus thompsoni) from Lake Ontario: the keystone predator hypothesis. Journal of Great Lakes Research 12:18-24. 
Brandt, S. B. 1986b. Ontogenetic shifts in habitat, diet, and diel-feeding periodicity of Slimy Sculpin in Lake Ontario. Transactions of the American Fisheries Society 115:711-715.

Bunnell, D. B., S. R. David, and C. P. Madenjian. 2009a. Decline in Bloater fecundity in southern Lake Michigan after decline of Diporeia. Journal of Great Lakes Research 35:45-49.

Bunnell, D. B., C. P. Madenjian, J. D. Holuszko, J. V. Adams, and J. R. P. French III. 2009b. Expansion of Dreissena into offshore waters of Lake Michigan and potential impacts on fish populations. Journal of Great Lakes Research 35:74-80.

Byron, C. J., and J. S. Link. 2010. Stability in the feeding ecology of four demersal fish predators in the US northeast shelf large marine ecosystem. Marine Ecology Progress Series 406:239-250.

Carreon-Martinez, L., T. B. Johnson, S. A. Ludsin, and D. D. Heath. 2011. Utilization of stomach content DNA to determine diet diversity in piscivorous fishes. Journal of Fish Biology 78:1170-1182.

Chotkowski, M. A., and J. E. Marsden. 1999. Round Goby and Mottled Sculpin predation on Lake Trout eggs and fry: field predictions from laboratory experiments. Journal of Great Lakes Research 25:26-35.

Christensen, V. 1995. A model of trophic interactions in the North Sea in 1981, the year of the stomach. Dana 11:1-28.

Christensen, V., and C. J. Walters. 2004. Ecopath with Ecosim: methods, capabilities and limitations. Ecological Modelling 172:109-139.

Christie, W. J. 1974. Changes in the fish species composition of the Great Lakes. Journal of the Fisheries Research Board of Canada 31:827-854.

Daan, N., A. D. Rijnsdorp, and G. R. van Overbeeke. 1985. Predation by North Sea herring Clupea harengus on eggs of plaice Pleuronectes platessa and cod Gadus morhua. Transactions of the American Fisheries Society 114:499-506.

Davis, B. M., J. F. Savino, and L. M. Ogilvie. 2007. Diet niches of major forage fish in Lake Michigan. Advances in Limnology 60:261-275.

Dermott, R. 2001. Sudden disappearance of the amphipod Diporeia from eastern Lake Ontario, 1993-1995. Journal of Great Lakes Research 27:423433.

Diana, J. S. 2005. Biology and ecology of fishes. Cooper Publishing Group, Carmel, Indiana.

Doubek, J. P., and J. T. Lehman. 2011. Historical biomass of Limnocalanus in Lake Michigan. Journal of Great Lakes Research 37:159-164.

Dubs, D. O. L., and L. D. Corkum. 1996. Behavioral interactions between Round Gobies (Neogobius melanostomus) and Mottled Sculpins (Cottus bairdi). Journal of Great Lakes Research 22:838-844.

Emery, L., and E. H. Brown Jr. 1978. Fecundity of the Bloater (Coregonus hoyi) in Lake Michigan. Transactions of the American Fisheries Society 107:785789.

Fitzsimons, J., B. Williston, G. Williston, G. Bravener, J. L. Jonas, R. M. Claramunt, J. E. Marsden, and B. J. Ellrott. 2006. Laboratory estimates of salmonine egg predation by Round Gobies (Neogobius melanostomus), sculpins (Cottus cognatus and C. bairdi), and crayfish (Orconectes propinquus). Journal of Great Lakes Research 32:227-241.

Foote, C. J., and G. S. Brown. 1998. Ecological relationship between freshwater sculpins (genus Cottus) and beach-spawning Sockeye Salmon (Oncorhynchus nerka) in Iliamna Lake, Alaska. Canadian Journal of Fisheries and Aquatic Sciences 55:1524-1533.

Francis, R. C., M. A. Hixon, M. E. Clarke, S. A. Murawski, and S. Ralston. 2007. Ten commandments for ecosystem-based fisheries scientists. Fisheries $32: 217-233$.

French, J. R. P., III. 1993. How well can fishes prey on zebra mussels in eastern North America? Fisheries 18(6):13-19.

French, J. R. P., I, J. V. Adams, J. Craig, R. G. Stickel, S. J. Nichols, and G. W. Fleischer. 2007. Shell-free biomass and population dynamics of dreissenids in offshore Lake Michigan, 2001-2003. Journal of Great Lakes Research 33:536-545.

French, J. R. P., III, and D. J. Jude. 2001. Diets and diet overlap of nonindigenous gobies and small benthic native fishes co-inhabiting the St. Clair River, Michigan. Journal of Great Lakes Research 27:300-311.
French, J. R. P., III, R. G. Stickel, B. A. Stockdale, and M. G. Black. 2010. A short-term look at potential changes in Lake Michigan Slimy Sculpin diets. Journal of Great Lakes Research 36:376-379.

García-Berthou, E. 2002. Ontogenetic diet shifts and interrupted piscivory in introduced Largemouth Bass (Micropterus salmoides). International Review of Hydrobiology 87:353-363.

Garrison, L. P., and J. S. Link. 2000a. Dietary guild structure of the fish community in the northeast United States continental shelf ecosystem. Marine Ecology Progress Series 202:231-240.

Garrison, L. P., and J. S. Link. 2000b. Diets of five hake species in the northeast United States continental shelf ecosystem. Marine Ecology Progress Series 204:243-255.

Geffen, A. J., and R. D. M. Nash. 1992. The life-history strategy of Deepwater Sculpin, Myoxocephalus thompsoni (Girard), in Lake Michigan: dispersal and settlement patterns during the first year of life. Journal of Fish Biology 41(Supplement B):101-110.

Ghedotti, M. J., J. C. Smihula, and G. R. Smith. 1995. Zebra mussel predation by Round Gobies in the laboratory. Journal of Great Lakes Research 21:665669.

Grossnickle, N. E., and A. M. Beeton. 1979. Antennal scale length as a measure of relative size in the opossum shrimp, Mysis relicta Lovén. Crustaceana 36:141-146.

Hanson, P. C., T. B. Johnson, D. E. Schindler, and J. F. Kitchell. 1997. Fish bioenergetics 3.0. University of Wisconsin, Sea Grant Institute, Technical Report WISCU-T-97-001, Madison.

Hebert, P. D. N., A. Cywinska, S. L. Ball, and J. R. deWaard. 2003. Biological identifications through DNA barcodes. Proceedings of the Royal Society of London B 270:313-321.

Hershey, A. E., and M. E. McDonald. 1985. Diet and digestion rates of Slimy Sculpin, Cottus cognatus, in an Alaskan arctic lake. Canadian Journal of Fisheries and Aquatic Sciences 42:483-487.

Hilborn, R., T. P. Quinn, D. E. Schindler, and D. E. Rogers. 2003. Biocomplexity and fisheries sustainability. Proceedings of the National Academy of Sciences of the USA 100:6564-6568.

Hillbricht-Ilkowska, A., and A. Stanczykowska. 1969. The production and standing crop of planktonic larvae of Dreissena polymorpha (Pall.) in two Mazurian lakes. Polskie Archiwum Hydrobiologii 16:193-203.

Hondorp, D. W., S. A. Pothoven, and S. B. Brandt. 2005. Influence of Diporeia density on diet composition, relative abundance, and energy density of planktivorous fishes in southeast Lake Michigan. Transactions of the American Fisheries Society 134:588-601.

Hondorp, D. W., S. A. Pothoven, and S. B. Brandt. 2011. Feeding selectivity of Slimy Sculpin Cottus cognatus and Deepwater Sculpin Myoxocephalus thompsonii in southeast Lake Michigan: implications for species coexistence. Journal of Great Lakes Research 37:165-172.

Hudson, P. L., L. T. Lesko, J. W. Reid, and M. A. Chriscinske 2003. Cyclopoid copepods of the Laurentian Great Lakes. Great Lakes Science Center, Ann Arbor, Michigan. Available: www.glsc.usgs.gov/ greatlakescopepods/Key.asp?GROUP = Cyclopoid. (April 2012).

Hunter, J. R., and C. A. Kimbrell. 1980. Egg cannibalism in the Northern Anchovy, Engraulis mordax. U.S. National Marine Fisheries Service Fishery Bulletin 78:811-816.

Ivanova, N. V., T. S. Zemlak, R. H. Hanner, and P. D. N. Hebert. 2007. Universal primer cocktails for fish DNA barcoding. Molecular Ecology Notes 7:544548.

Jackson, J. B. C., M. X. Kirby, W. H. Berger, K. A. Bjorndal, L. W. Botsford, B. J. Bourque, R. H. Bradbury, R. Cooke, J. Erlandson, J. A. Estes, T. P. Hughes, S. Kidwell, C. B. Lange, H. S. Lenihan, J. M. Pandolfi, C. H. Peterson, R. S. Steneck, M. J. Tegner, and R. R. Warner. 2001. Historical overfishing and the recent collapse of coastal ecosystems. Science 293:629-637.

Janssen, J., and D. J. Jude. 2001. Recruitment failure of Mottled Sculpin Cottus bairdi in Calumet Harbor, southern Lake Michigan, induced by the newly introduced Round Goby Neogobius melanostomus. Journal of Great Lakes Research 27:319-328. 
Jude, D. J. 2001. Round and Tubenose Gobies: 10 years with the latest Great Lakes phantom menace. Dreissena! (National Aquatic Nuisance Species Clearinghouse, SUNY, Brockport, New York) 11:1-14.

Jude, D. J., R. H. Reider, and G. R. Smith. 1992. Establishment of Gobiidae in the Great Lakes basin. Canadian Journal of Fisheries and Aquatic Sciences 49:416-421.

Kaufman, L. 1992. Catastrophic change in species-rich freshwater ecosystems: the lessons of Lake Victoria. BioScience 42:846-858.

Köster, F. W., and C. Möllmann. 2000. Trophodynamic control by clupeid predators on recruitment success in Baltic cod? ICES Journal of Marine Science 57:310-323.

Kraft, C. E., and J. F. Kitchell. 1986. Partitioning of food resources by sculpins in Lake Michigan. Environmental Biology of Fishes 16:309316

Lantry, B. F., R. O’Gorman, M. G. Walsh, J. M. Casselman, J. A. Hoyle, M. J. Keir, and J. R. Lantry. 2007. Reappearance of Deepwater Sculpin in Lake Ontario: resurgence or last gasp of a doomed population? Journal of Great Lakes Research 33(Supplement 1):34-45.

Lesko, L. T., P. L. Hudson, and M. A. Chriscinske. 2003. Calanoid copepods of the Laurentian Great Lakes. Great Lakes Science Center, Ann Arbor, Michigan. Available: www.glsc.usgs.gov/greatlakescopepods/Key.asp?GROUP = Calanoid. (April 2012).

Link, J. S. 2002. Ecological considerations in fisheries management: when does it matter? Fisheries 27(4):10-17.

Link, J. S., J. Burnett, P. Kostovick, and J. Galbraith. 2008. Value-added sampling for fishery independent surveys: don't stop after you're done counting and measuring. Fisheries Research 93:229-233.

Link, J. S., L. P. Garrison, and F. P. Almeida. 2002. Ecological interactions between elasmobranchs and groundfish species on the northeastern U.S. continental shelf: I. evaluation predation. North American Journal of Fisheries Management 22:550-562.

Londer, J. G. 2011. Diet overlap and food habits of Slimy Sculpin, Deepwater Sculpin, and Round Goby during winter in offshore Lake Michigan. Master's thesis. University of Michigan, Ann Arbor.

Lozano, S. 2011. Final report: status macroinvertebrates in the Lake Ontario. The College at Brockport, Technical Reports, Paper 67, State University of New York, Brockport. Available: digitalcommons.brockport.edu/tech_rep/67. (November 2012).

Luecke, C., J. A. Rice, L. B. Crowder, S. E. Yeo, and F. P. Binkowski. 1990. Recruitment mechanisms of Bloater in Lake Michigan: an analysis of the predatory gauntlet. Canadian Journal of Fisheries and Aquatic Sciences 47:524 532

Madenjian, C. P., D. B. Bunnell, T. J. DeSorcie, M. A. Chriscinske, M. J. Kostich, and J. V. Adams. 2012. Status and trends of prey fish populations in Lake Michigan, 2011. Report to Lake Michigan Committee, Great Lakes Fishery Commission, Ann Arbor, Michigan. Available: www.glsc.usgs.gov/_files/reports/2011LakeMichiganPreyfishReport.pdf. (April 2012)

Madenjian, C. P., R. F. Elliott, T. J. DeSorcie, R. M. Stedman, D. V. O'Connor, and D. V. Rottiers. 2000. Lipid concentrations in Lake Michigan fishes: seasonal, spatial, ontogenetic, and long-term trends. Journal of Great Lakes Research 26:427-444.

Makarewicz, J. C., and H. D. Jones. 1990. Occurrence of Bythotrephes cederstroemi in Lake Ontario offshore waters. Journal of Great Lakes Research 16:143-147.

Martin, F. D. 1984. Diets of four sympatric species of Etheostoma (Pisces: Percidae) from southern Indiana: interspecific and intraspecific multiple comparisons. Environmental Biology of Fishes 11:113-120.

Miller, P. J. 1986. Gobiidae. Pages 1019-1085 in P. J. P. Whitehead, M. L. Bauchot, J. C. Hureau, J. Nielsen, and E. Tortonese, editors. Fishes of the north-eastern Atlantic and the Mediterranean, volume 3. United Nations Educational, Scientific and Cultural Organization, Paris.

Miller, R. R., J. D. Williams, and J. E. Williams. 1989. Extinction of North American fishes during the past century. Fisheries 14(6):22-38.
Mills, E. L., J. H. Leach, J. T. Carlton, and C. L. Secor. 1993. Exotic species in the Great Lakes: a history of biotic crises and anthropogenic introductions. Journal of Great Lakes Research 19:1-54.

Nalepa, T. F., D. L. Fanslow, and G. A. Lang. 2009. Transformation of the offshore benthic community in Lake Michigan: recent shift from the native amphipod Diporeia spp. to the invasive mussel Dreissena rostriformis bugensis. Freshwater Biology 54:466-479.

Nalepa, T. F., D. L. Fanslow, and S. A. Pothoven. 2010. Recent changes in density, biomass, recruitment, size structure, and nutritional state of Dreissena populations in southern Lake Michigan. Journal of Great Lakes Research 36:5-19.

Nalepa, T. F., and M. A. Quigley. 1980. The macro- and meiobenthos of southeastern Lake Michigan near the mouth of the Grand River, 1976-77. NOAA (National Oceanic and Atmospheric Administration) Data Report ERL GLERL-17, Great Lakes Environmental Research Laboratory, Ann Arbor, Michigan.

O'Brien, T. P., E. F. Roseman, C. S. Kiley, and J. S. Schaeffer. 2009. Fall diet and bathymetric distribution of Deepwater Sculpin (Myoxocephalus thompsonii) in Lake Huron. Journal of Great Lakes Research 35:464-472.

Owens, R. W., and D. E. Dittman. 2003. Shifts in the diets of Slimy Sculpin (Cottus cognatus) and Lake Whitefish (Coregonus clupeaformis) in Lake Ontario following the collapse of the burrowing amphipod Diporeia. Aquatic Ecosystem Health and Management 6:311-323.

Owens, R. W., and G. E. Noguchi. 1998. Intra-lake variation in maturity, fecundity, and spawning of Slimy Sculpins (Cottus cognatus) in southern Lake Ontario. Journal of Great Lakes Research 24:383-391.

Pace, M. L., and J. D. Orcutt Jr. 1981. The relative importance of protozoans, rotifers, and crustaceans in a freshwater zooplankton community. Limnology and Oceanography 26:822-830.

Pikitch, E. K., C. Santora, E. A. Babcock, A. Bakun, R. Bonfil, D. O. Conover, P. Dayton, P. Doukakis, D. Fluharty, B. Heneman, E. D. Houde, J. S. Link, P. A. Livingston, M. Mangel, M. K. McAllister, J. Pope, and K. J. Sainsbury. 2004. Ecosystem-based fishery management. Science 305:346347.

Pitcher, T. J. 2001. Fisheries managed to rebuild ecosystems? reconstructing the past to salvage the future. Ecological Applications 11:601-617.

Pothoven, S. A., D. W. Hondorp, and T. F. Nalepa. 2011. Declines in Deepwater Sculpin Myoxocephalus thompsonii energy density associated with the disappearance of Diporeia spp. in Lakes Huron and Michigan. Ecology of Freshwater Fish 20:14-22.

Pothoven, S. A., and C. P. Madenjian. 2008. Changes in consumption by Alewives and Lake Whitefish after dreissenid mussel invasions in Lakes Michigan and Huron. North American Journal of Fisheries Management 28:308-320.

Pothoven, S. A., and T. F. Nalepa. 2006. Feeding ecology of Lake Whitefish in Lake Huron. Journal of Great Lakes Research 32:489-501.

Pothoven, S. A., T. F. Nalepa, P. J. Schneeberger, and S. B. Brandt. 2001. Changes in diet and body condition of Lake Whitefish in southern Lake Michigan associated with changes in benthos. North American Journal of Fisheries Management 21:876-883.

Prejs, A., K. Lewandowski, and A. Stańczykowska-Piotrowska. 1990. Sizeselective predation by Roach (Rutilus rutilus) on zebra mussel (Dreissena polymorpha): field studies. Oecologia 83:378-384.

Rahel, F. J. 2002. Homogenization of freshwater faunas. Annual Review of Ecology and Systematics 33:291-315.

Ray, W. J., and L. D. Corkum. 1997. Predation of zebra mussels by Round Gobies, Neogobius melanostomus. Environmental Biology of Fishes 50:267273.

Rice, J. A., L. B. Crowder, and M. E. Holey. 1987. Exploration of mechanisms regulating larval survival in Lake Michigan Bloater: a recruitment analysis based on characteristics of individual larvae. Transactions of the American Fisheries Society 116:703-718.

Richardson, D. E., J. A. Hare, M. J. Fogarty, and J. S. Link. 2011. Role of egg predation by Haddock in the decline of an Atlantic Herring population. 
Proceedings of the National Academy of Sciences of the USA 108:1360613611.

Rosel, P. E., and T. D. Kocher. 2002. DNA-based identification of larval cod in stomach contents of predatory fishes. Journal of Experimental Marine Biology and Ecology 267:75-88.

Roseman, E. F., D. J. Jude, M. K. Raths, T. G. Coon, and W. W. Taylor. 1998. Occurrence of the Deepwater Sculpin (Myoxocephalus thompsoni) in western Lake Erie. Journal of Great Lakes Research 24:479-483.

Roseman, E. F., W. W. Taylor, D. B. Hayes, A. L. Jones, and J. T. Francis. 2006. Predation on Walleye eggs by fish on reefs in western Lake Erie. Journal of Great Lakes Research 32:415-423.

Rosen, R. A. 1981. Length-dry weight relationships of some freshwater zooplankton. Journal of Freshwater Ecology 1:225-229.

Rottiers, D. V. 1965. Some aspects of the life history of Cottus cognatus in Lake Michigan. Master's thesis. University of Michigan, Ann Arbor.

Schaeffer, J. S., A. Bowen, M. Thomas, J. R. P. French III, and G. L. Curtis. 2005. Invasion history, proliferation, and offshore diet of the Round Goby Neogobius melanostomus in western Lake Huron, USA. Journal of Great Lakes Research 31:414-425.

Schoener, T. W. 1970. Nonsynchronous spatial overlap of lizards in patchy habitats. Ecology 51:408-418.

Scott, M. C., and G. S. Helfman. 2001. Native invasions, homogenization, and the mismeasure of integrity of fish assemblages. Fisheries 26(11):6-15.

Shea, M. A., and J. C. Makarewicz. 1989. Production, biomass, and trophic interactions of Mysis relicta in Lake Ontario. Journal of Great Lakes Research 15:223-232.

Smith, S. H. 1968. Species succession and fishery exploitation in the Great Lakes. Journal of the Fisheries Research Board of Canada 25:667-693.

Steinhart, G. B., E. A. Marschall, and R. A. Stein. 2004. Round Goby predation on Smallmouth Bass offspring in nests during simulated catch-and-release angling. Transactions of the American Fisheries Society 133:121-131.

Tyus, H. M., and J. F. Saunders III. 2000. Nonnative fish control and endangered fish recovery: lessons from the Colorado River. Fisheries 25(9):17-24.
Vanderploeg, H. A., T. F. Nalepa, D. J. Jude, E. L. Mills, K. T. Holeck, J. R. Liebig, I. A. Grigorovich, and H. Ojaveer. 2002. Dispersal and emerging ecological impacts of Ponto-Caspian species in the Laurentian Great Lakes. Canadian Journal of Fisheries and Aquatic Sciences 59:12091228.

Vanderploeg, H. A., S. A. Pothoven, G. L. Fahnenstiel, J. F. Cavaletto, J. R. Liebig, C. A. Stow, T. F. Nalepa, C. P. Madenjian, and D. B. Bunnell. 2012. Seasonal zooplankton dynamics in Lake Michigan: disentangling impacts of resource limitation, ecosystem engineering, and predation during a critical ecosystem transition. Journal of Great Lakes Research 38:336-352.

Vila-Gispert, A., M. G. Fox, L. Zamora, and R. Moreno-Amich. 2007. Morphological variation in Pumpkinseed Lepomis gibbosus introduced into Iberian lakes and reservoirs; adaptations to habitat type and diet? Journal of Fish Biology 71:163-181.

Walsh, M. G., D. E. Dittman, and R. O'Gorman. 2007. Occurrence and food habits of the Round Goby in the profundal zone of southwestern Lake Ontario. Journal of Great Lakes Research 33:83-92.

Wells, L. 1980. Food of Alewives, Yellow Perch, Spottail Shiners, Trout-perch, and Slimy and Fourhorn Sculpins in southeastern Lake Michigan. U.S. Fish and Wildlife Service, Technical Paper 98, Great Lakes Science Center, Ann Arbor, Michigan.

Wells, L., and A. L. McLain. 1973. Lake Michigan: man's effects on native fish stocks and other biota. Great Lakes Fishery Commission Technical Report 20.

Winemiller, K. O. 1989. Ontogenetic diet shifts and resource partitioning among piscivorous fishes in the Venezuelan llanos. Environmental Biology of Fishes 26:177-199.

Wojcik, J. A., M. S. Evans, and D. J. Jude. 1986. Food of Deepwater Sculpin, Myoxocephalus thompsoni, from southeastern Lake Michigan. Journal of Great Lakes Research 12:225-231.

Zimmerman, M. S., and C. C. Krueger. 2009. An ecosystem perspective on re-establishing native deepwater fishes in the Laurentian Great Lakes. North American Journal of Fisheries Management 29:1352-1371. 